\title{
Influence of Inquiry Learning Strategy and Locus of Control on Students' Environmental Knowledge
}

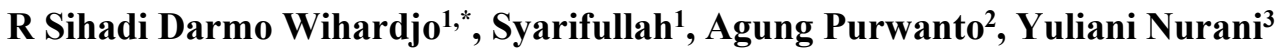 \\ ${ }^{1}$ Department of Environmental Education, Graduate Program, Universitas Negeri Jakarta, Indonesia \\ ${ }^{2}$ Department of Chemistry Education, Faculty of Mathematics and Natural Science, Universitas Negeri Jakarta, Indonesia \\ ${ }^{3}$ Department of Early Childhood Education, Faculty of Education, Universitas Negeri Jakarta, Indonesia
}

Received November 1, 2019; Revised January 13, 2020; Accepted February 24, 2020

Copyright $\odot 2020$ by authors, all rights reserved. Authors agree that this article remains permanently open access under the terms of the Creative Commons Attribution License 4.0 International License

\begin{abstract}
Environmental and natural resources damage has come to a very alarming level. For that, students should be given awareness to care for the environment. This can be done by providing understanding of the environment to the students, through a good learning strategy. The study aims to determine the environmental knowledge of students in schools that are the locus of control (high and low) and learning strategies (guided inquiry and open-ended inquiry). The variables into the research object are the environmental knowledge of students in the school (Y), and the Strategy of Learning Inquiry (X1) on locus of Control (X2). The population in this study is all students of the grade XI IPA Madrasah Alawiyah Alwathoniyah 43 North Jakarta, consisting of 3 classes with the number of each consisting of 30 students. Based on the results of the study can be concluded that there is influence of the strategy of learning inquiry and locus of control to the student's environmental knowledge. Furthermore, the results of the study explain that the knowledge of environmental students taught by Open-ended inquiry learning strategy will have a maximum value if used in the low locus of control group, while the high locus of control group Highest score when taught by the strategy of learning guided inquiry.
\end{abstract}

Keywords Inquiry Learning Strategy, Locus of Control, Environmental Knowledge

\section{Introduction}

Environmental and natural resources damage has come to a very alarming level. Environmental damage is not only perceived by local and national people but also on a global scale. Many of the events that have been happening, such as flooding, air pollution, rivers polluted waste, and many more can result in damage to the environment and ecosystem [1]. Addressing the destruction of environmental and natural resources, there needs to be the environmental knowledge of students at school and skills that are directly in the application of daily life and become a pattern of action and mindset for the handling. More specific to the problems faced by the Indonesian nation in general, especially in Jakarta society that has been very urgent problem that is handling waste, air pollution, wastewater, as well as conservation of nature as the city's lungs and as a water supply place [2]. This includes the need to dispose of all waste as a consequence of human activity.

Assessment is part of the teacher's accountability that is much needed in learning. The development of students in school should be measured to see what competencies the students have obtained through the learning process $[3,4]$

Students at the school of Madrasah Alawiyah Alwathoniyah 43 Jakarta North is a part of the community, the young generation of the future success of a nation that will live in the future and will face a high challenge of life with all the problems which complex. For that, students must awaken their consciousness to care for the environment, so that attitudes and mindsets and behaviors, the understanding of the environment are increasing.

Bloom further classifies the aspects of knowledge in three groups detailed from nine points: 1) Knowledge of matters of particular nature includes: terms and facts, 2) knowledge on how to address issues Special things include: habits, likelihood, classifications, categories, methods, and 3) knowledge of universal rules including: Principles and Structures [5]. Results show that the nature of cognitive development is the development of formal operational thinking ability with characterized by abstract thinking abilities and the ability to deduct-hypothetical thinking, individual development in cognitive ability cannot be measured in general, because there are still 
factors determinant that determines cognitive skills, such as culture and social environment [6].

The environment under LAW No. 322009 on environmental management and protection is the unity of space with all objects, power, circumstances, and living creatures, including in humans and their behavior, affecting the continuity of Life and Kesejahtraan of humanity and other living creatures [7]. Concerning maintaining the environment, the motivation described as an encouragement to be able to realize the purpose or needs of one must be attributed to the use of preserving the environment [8]. Changes in both absolute and relative from environmental factors to plants will differ according to time, place and state of the plant itself [9]. Learning is an activity that is consciously done to produce a change, concerning knowledge, this is because it gives the environment, attitudes and values.

Aside from that, the selection of monolithic learning strategies during this time allegedly contributes to the emergence of obstacles to the problem of solving environmental problems [10]. While Made Wina defines a strategy of learning as a special action by a person to facilitate, accelerate, more enjoy, more comfortable to understand directly, more effective and more comfortable to transfer into the situation The new one [11]. Inquiry as a general process done by man to seek or understand information [12]. A teacher expects good results in the learning process will apply a strategy learning inquiry that is influenced by many factors, and one of them is locus of control students. It is based on the assumption that without the locus of control students, then a concept shows on the individual belief about the events that occurred in his life. The locus of control students describes how far the students looked at the relationship between the deeds that were instituted.

Locus of control is a personality element. The element grows and develops from the background of one's life. People who have a high self-concept, experience the psychological situation is more reliable. The environmental situation that supports a sense of security gives satisfaction and encourages motivation to achieve achievement, it is also a characteristic of people who have an internal locus of control [13]. According to Soemanto [14], Locus of Control is how the individual feels/sees the line/relationship between his behavior and consequently, whether he can accept responsibility or not for his actions.

Based on the description and background of the above issues, researchers are interested in researching the title "influence of inquiry learning strategy and locus of control on students' environmental knowledge".

\subsection{Research Objectives}

In accordance with the problems that have been formulated, this research aims to know the factors of influence between the strategy of learning inquiry and locus of control to the environmental knowledge of students in school. The specific objectives of this study include the following:

1. To know the environmental knowledge of students in schools that are high of locus control to the Strategic Learning guided Inquiry and open-ended inquiry

2. To know the environmental knowledge of students in schools that are low of locus control towards strategy learning guided Inquiry and open-ended inquiry

\section{Methodology}

This study was conducted on the environment of students of Madrasah Alawiyah Al Wathoniyah 43 North Jakarta school year 2018/2019. The collection of research data was conducted in December 2018.

The method used in this research is the experimental method. The experimental method is used to examine the presence of influence by providing treatment of the experimental class that results compared to the control class $[15,16]$.

There are three variables in this study consisting of two free variables and one bound variable. Independent variables in this research are strategies for Learning Inquiry (A) and locus of control (B). While the variable bound is the student's environmental Knowledge (Y).

The population of this study is the student of class XI IPA Madarasah Alawiyah Al Wathoniyah 43 North Jakarta, which is listed in the school year 2018/2019 consisting of 3 classes with a total of 30 students. The sampling techniques used are simple random sampling techniques. Samples were taken by the high locus of control students who in the classroom numbered only eight people, and students of low locus of control were randomly selected from each class of experimentation and control class of 3 class XI. The two types of samples will be given the treatment of different methods of learning, namely the experimental class with guided inquiry strategies and control class with open-ended Inquiry learning strategy.

The design of the treatment used there are two stages, namely the first phase of determining the sample area/class, and the next stage to determine the people in the region/class is in random sampling also. To obtain the data in this study used questionnaires for the three variables, i.e. the strategy of Learning Inquiry (X1), and locus of Control (X2), on the student's environmental Knowledge (Y).

\section{Results and Discussion}

\subsection{Description of Student Environment Knowledge with the Learning Strategy of Guided Inquiry and High Locus of Control}

The students' environmental knowledge with guided 
Inquiry and high locus of control can be seen in Table 1 below.

Table 1. Frequency distribution of students' environmental knowledge with guided Inquiry strategies and High locus of control

\begin{tabular}{|c|c|c|c|c|c|c|}
\hline No. & Value & $F$ & Lower limit & Upper limit & $F \mathrm{k}$ & $\begin{array}{c}F \mathrm{r} \\
(\%)\end{array}$ \\
\hline 1 & $24-25$ & 1 & 23.5 & 25.5 & 1 & 12.5 \\
\hline 2 & $26-27$ & 2 & 25.5 & 27.5 & 3 & 25.0 \\
\hline 3 & $28-29$ & 3 & 27.5 & 29.5 & 6 & 37.5 \\
\hline 4 & $30-31$ & 2 & 29.5 & 31.5 & 8 & 25.0 \\
\hline & Sum & 8 & & & & 100 \\
\hline
\end{tabular}

According to table 1 above, it can be explained that the number of students earning a score in the interval class of 24-25 there is 1 person (12.5\%), students who acquire at interval class $26-27$ There are 2 people $(25.0 \%)$, students who score at interval class $28-29$ There were 3 people (37.5\%), students who gained the interval class of 30-31 were 2 people $(25.0 \%)$. The results of environmental knowledge of students with learning strategy guided inquiry and high locus of control can be seen from an average value of 27.5 with a sample number of 8 students with the highest score range of 31 and the lowest score of 24. Histogram of the data description can be seen in Figure 1 below.

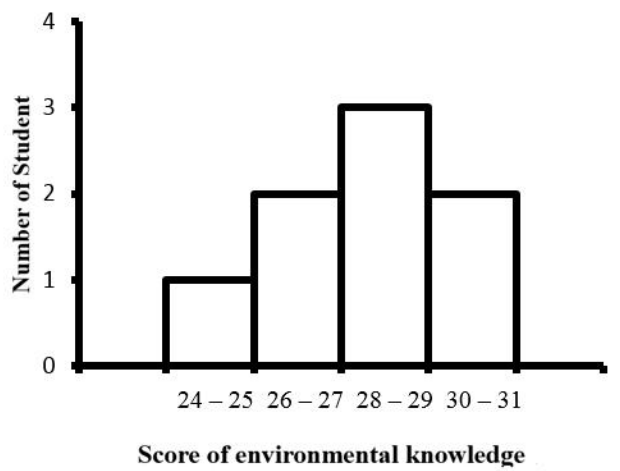

Figure 1. Histogram of Students' environmental knowledge with guided Inquiry strategies and High locus of control

\subsection{Description of Student Environment Knowledge with Guided Inquiry Strategy and Low Locus of Control}

Environmental knowledge Data of students with guided inquiry strategy and low locus of control can be seen in Table 2 below.
Table 2. Frequency distribution of students' environmental knowledge with guided Inquiry strategies and low locus of control

\begin{tabular}{|c|c|c|c|c|c|c|}
\hline No. & Value & $F$ & Lower limit & Upper limit & $F \mathrm{k}$ & $\begin{array}{c}F \mathrm{r} \\
(\%)\end{array}$ \\
\hline 1 & $17-18$ & 2 & 16.5 & 18.5 & 2 & 25.5 \\
\hline 2 & $19-20$ & 4 & 18.5 & 20.5 & 6 & 50.0 \\
\hline 3 & $21-22$ & 1 & 20.5 & 22.5 & 7 & 12.5 \\
\hline 4 & $23-24$ & 1 & 22.5 & 24.5 & 8 & 12.5 \\
\hline & Sum & 8 & & & & 100 \\
\hline
\end{tabular}

According to Table 2 above it can be explained that the number of students earning a score on the interval class of 17-18 There are 2 people (25.0\%), students who acquire at interval class 19-20 There are 4 people $(50.0 \%)$, students who score at interval class $21-22$ there 1 ora $\mathrm{Ng}(12.5 \%)$, students who obtained the interval class of 23-24 were 1 person (12.5\%). The results of environmental knowledge of students with guided inquiry strategy and low locus of control can be seen from an average value of 20.5 with a sample number of 8 students with the highest score range of 24 and a low score of 17. The Histogram of the distribution list can be seen figure 2 below.

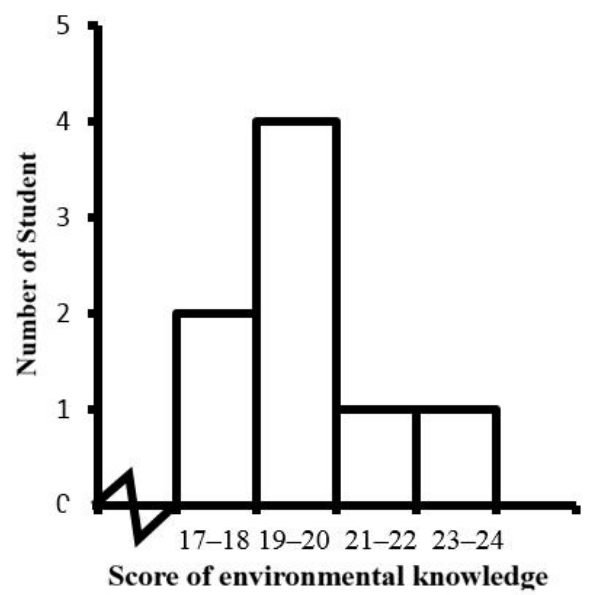

Figure 2. Graphic of environmental knowledge students with guided inquiry strategy and low locus of control

\subsection{Description of Student Environment Knowledge with Open-Ended Inquiry Strategy and High Locus of Control}

Students' environmental knowledge with open-ended inquiry strategies and high locus of control can be seen in Table 3 below. 
Table 3. Frequency distribution of students' environmental knowledge with open-ended Inquiry strategies and high locus of control

\begin{tabular}{|c|c|c|c|c|c|c|}
\hline No. & Value & $F$ & Lower limit & Upper limit & $F \mathrm{k}$ & $\begin{array}{c}F \mathrm{r} \\
(\%)\end{array}$ \\
\hline 1 & $16-17$ & 2 & 15.5 & 17.5 & 2 & 25.0 \\
\hline 2 & $18-19$ & 3 & 17.5 & 19.5 & 5 & 37.5 \\
\hline 3 & $20-21$ & 2 & 29.5 & 21.5 & 7 & 25.0 \\
\hline 4 & $22-23$ & 1 & 21.5 & 23.5 & 8 & 12.5 \\
\hline & Sum & 8 & & & & 100 \\
\hline
\end{tabular}

According to Table 3 above it can be explained that the number of students earning a score on the interval class of 16-17 There are 2 persons (25.0\%), students who acquire at interval class $18-19$ There are 3 persons $(37.5 \%)$, students who score at interval Class 20-21 There are $2 \mathrm{G}$ $(25.0 \%)$, students who acquired the interval class of 22-23 were 1 person (12.5\%). The results of students' environmental knowledge with open-ended inquiry strategy and high locus of control can be seen from an average value of 19.5 with a sample number of 8 students with the highest score range of 23 and the lowest score of 16. It is because of several factors that affect students more interest in environmental learning.

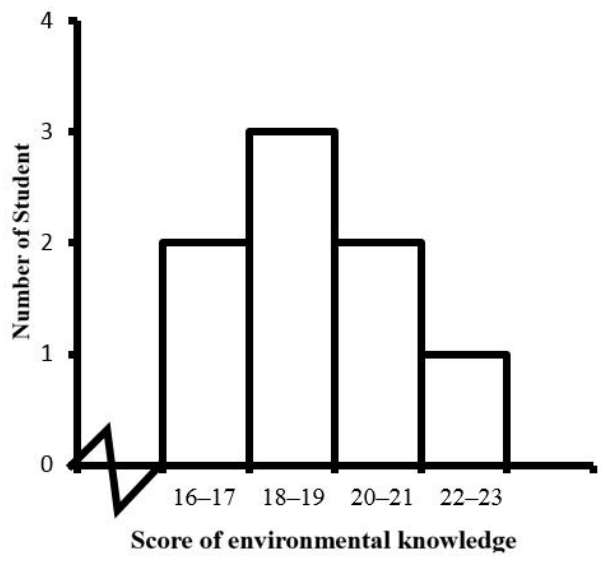

Figure 3. Graph of students' environmental knowledge with open-ended Inquiry strategy and high locus of control

\subsection{Description of Student Environment Knowledge with Open-Ended Inquiry Strategy and Low Locus of Control}

Students' environmental knowledge with open-ended inquiry strategy and low locus of control can be seen in Table 4 below.

Table 4. Frequency distribution of Knowledge environment students with open-ended Inquiry learning strategy and low locus of control

\begin{tabular}{|c|c|c|c|c|c|c|}
\hline No. & Value & $F$ & Lower limit & Upper limit & $F \mathrm{k}$ & $\begin{array}{c}F \mathrm{r} \\
(\%)\end{array}$ \\
\hline 1 & $19-20$ & 1 & 18.5 & 20.5 & 1 & 12.5 \\
\hline 2 & $21-22$ & 1 & 20.5 & 22.5 & 2 & 12.5 \\
\hline 3 & $23-24$ & 4 & 22.5 & 24.5 & 6 & 50.0 \\
\hline 4 & $25-26$ & 2 & 24.5 & 26.5 & 8 & 25.5 \\
\hline & Sum & 8 & & & & 100 \\
\hline
\end{tabular}

According to table 4 above, it can be explained that the number of students earning a score in the interval class of 16-17 There are 2 persons (25.0\%), students who acquire at interval class $19-20$ there 1 person $(12.5 \%)$, students who score at interval class 21-22 there 1 Oran G (20.5\%), students who gained at interval class 23-24 were 4 people $(50.0 \%)$. The results of students' environmental knowledge with open-ended inquiry strategy and low locus of control can be seen from an average value of 20.5 with a sample number of 8 students with the highest score range of 26 and a score of 19. The Histogram of the distribution list can be seen figure 4 below.

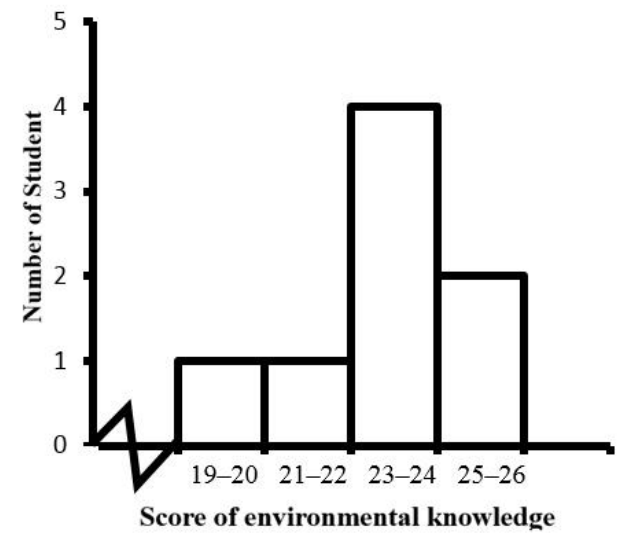

Figure 4. Graphic of knowledge environment students with open-ended Inquiry strategy and low locus of control

Locus of control is a personality element. The element grows and develops from the background of one's life. People who have a high self-concept, experience the psychological situation is more ajeg. The environmental situation that supports a sense of security gives satisfaction and encourages motivation to achieve achievement, it is also a characteristic of people who have internal locus of control [13]. According to Soemanto [14], Locus of Control is how the individual feels/sees the line/relationship between his behavior and consequently, whether he can accept responsibility or not for his actions. The locus of control is a construction that leads to the perception of self-control over the environment affecting a person's life. Students with internal locus of control will have the basic ability to capture problems, make decisions, solve problems related to the ability to improve religious attitudes by utilizing existing means

\section{Conclusions}

Based on the results of the study, it was concluded that the students' environmental knowledge taught with open-ended Inquiry strategy would have a maximum value if used in the low locus of control group, while the high of locus control group gets maximum value when taught by the Inquiry guided Strategy. This is because of several factors that affect the Strategy learning inquiry to 
the students are demanding to solve environmental problems to the surrounding circumstances so that students with high locus of control will be more easily receive Taught with guided learning inquiry. Secondly, low locus of control students learning better by using open-ended inquiry learning strategy. This is because in the strategy of teaching open-ended inquiry, teacher role as facilitator during the learning process takes place passive role. But at the end of the study, teachers will provide assessment and constructive inputs, so that students can undergo a better learning process.

\section{REFERENCES}

[1] Yuniarto, B.: 'Membangun Kesadaran Warga Negara dalam Pelestarian Lingkungan' (Deepublish, 2013. 2013)

[2] Manik, K.E.S.: 'Pengelolaan lingkungan hidup' (Kencana, 2018. 2018)

[3] Ramadhan, S., Mardapi, D., Sahabuddin, C., \& Sumiharsono, R. (2019). The estimation of standard error measurement of physics final examination at senior high schools in bima regency indonesia. Universal Journal of Educational Research, 7(7), 1590-1594.https://doi.org/10.13189/ujer.2019.070713

[4] Ramadhan, S., Nasran, S. A., Utomo, H. B., Musyadad, F., \& Ishak, S. (2019). The Implementation of generalisability theory on physics teachers' competency assessment instruments development. International Journal of Scientific and Technology Research, 8(7), 333-337.

[5] Anderson, L., and Krathwohl, D.: 'A taxonomy for learning teaching and assessment: a revision af bloom's taxonomy of education objectives', in Editor (Ed.)^(Eds.): 'Book A taxonomy for learning teaching and assessment: a revision af bloom's taxonomy of education objectives' (New York, San Fransisko, Boston: Addison Wesley Longman, Inc, 2001, edn.), pp.

[6] Khiyarusoleh, U.: 'Konsep Dasar Perkembangan Kognitif pada Anak Menurut Jean Piaget', Dialektika: Jurnal Pemikiran dan Penelitian Pendidikan Dasar, 2016, 5, (1)

[7] Zulkifli, A.: 'Dasar-dasar ilmu lingkungan', Jakarta: Salemba Teknika, 2014

[8] Wihardjo, S.D., and Sujarwanta, A.: 'Studi korelasional pengetahuan kearifan lokal, sikap terhadap lingkungan, dan motivasional konservasi dengan partisipasi pemuda dalam konservasi pesisir', Jurnal lentera pendidikan pusat penelitian LPPM UM METRO, 2016, 1, (2), pp. 146-161

[9] Irwan, Z.a.D.: 'Prinsip-Prinsip Ekologi Ekosistem, Lingkungan, dan Pelestariannya', Jakarta: Bumi Aksara, 2007

[10] Purwanto, A.: 'Pengaruh Paket Pembelajaran Pendidikan Lingkungan Hidup Dan Gaya Kognitif Terhadap Kemampuan Memecahkan Masalah Lingkungan (Studi Eksperimen Pada Jurusan Kimia, Fmipa Universitas Negeri Jakarta)', Jurnal Pendidikan Lingkungan dan Pembangunan Berkelanjutan, 2012, 13, (1), pp. 55-68
[11] Gulo, W.: 'Metodologi Penelitian, Grasindo(Gramedia Widiasarana Indonesia)', in Editor (Ed.) ${ }^{\wedge}($ Eds.): 'Book Metodologi Penelitian, Grasindo(Gramedia Widiasarana Indonesia)' (Jakarta, 2002, edn.), pp.

[12] Trianto, S.P., and Pd, M.: 'Model-model pembelajaran inovatif berorientasi Konstruktivistik', Jakarta: Prestasi Pustaka, 2007

[13] Sinaga, A. J., Sitompul, H., \& Sukirno, S. (2017). Pengaruh Strategi Pembelajaran dan Locus Of Control Terhadap Hasil Belajar Pendidikan Agama Siswa Kelas XI SMA Swasta St. Thomas 2 Medan. TABULARASA, 14(2), 119-128.

[14] Soemanto, W. (2006). Psikologi pendidikan: Landasan kerja pemimpin pendidikan (Cetakan ke 5). Jakarta: Rineka Cipta.

[15] Sofyan, H., \& Anggereini, E. (2019). Developing the reference books of center, area and group learning models based on environment and thematic in early childhood education Universal Journal of Educational Research, 7(10), 2208-2213. doi: 10.13189/ujer.2019.071019.

[16] Sofyan, H., Anggereini, E., \& Saadiah, J. (2019). Development of E-modules based on local wisdom in central learning model at kindergartens in jambi city. European Journal of Educational Research, 8(4), 1137-1143. doi: 10.12973/eu-jer.8.4.1139 